\title{
The Inaccessible Road Not Taken: The Trials, Tribulations And Successes Of Disability Inclusion Within Social Work Post-Secondary Education
}

\author{
Irene Carter, PhD., University of Windsor \\ Roy Hanes, PhD., Carleton University \\ Judy E. MacDonald, PhD., Dalhousie University
}

\begin{abstract}
The authors share a common vision with respect to social justice and disability rights, displaying a common interest in making professional post-secondary education more responsive to persons with disabilities. While the focus of this research and advocacy is stemming from the work of the Canadian Association of Social Work Education, Persons with Disabilities Caucus, the authors believe it is transferable and applicable to any faculty, school or department within an academic setting. Within this paper, the authors will highlight eighteen years of work by the caucus including the initial formation of this group, a small group of academics across Canada who joined together with the purpose of transforming post-secondary social work education into an accessible, inclusive environment for disabled persons. Further, the authors will report on research findings related to disability inclusion within Canadian schools of social work, drawing upon the data from the initial survey in 2003 (Dunn, Hanes, Hardie, \& MacDonald, 2006), with the primary focus on the most recent survey in 2010 - 2011. Finally, the authors will conclude this paper by presenting the barriers they faced while bringing about curricular and structural changes and the lessons learned from their journey. In essence, they will demonstrate how academics can unite to challenge post-secondary institutions in becoming more accessible to persons with disabilities.
\end{abstract}

\section{Keywords}

Disability; Inclusion; Accessibility; Education; Social Work; Curriculum; Activism 


\section{The Inaccessible Road Not Taken: The Trials, Tribulations And Successes Of Disability Inclusion Within Social Work Post-Secondary Education}

\section{Introduction}

In this paper, the authors will share their collective experiences, including the struggles and achievements toward making the profession of social work, social work education, schools of social work and universities more accessible and accommodating to people with disabilities. Within Canada 4.4 million people live with a disability, representing $14.3 \%$ of the population (Human Resource and Skill Development Canada, 2007). Between 2001 and 2006, the number of people who reported having a disability had increased by $21.2 \%$. The population of people with disabilities in Canada is growing and research shows that far too many youth with disabilities face enormous difficulties transitioning from adolescence to adulthood (LewisFleming, 2007; Milsom \& Hartley, 2005). And, because of the lack of availability of supports and services, as well as accessible colleges and universities, many have very limited opportunities to gain a post-secondary education. "Nearly half of Canadians agree that even if they could afford tuition, groups such as Aboriginals and disabled persons, would still face significant difficulties attending post-secondary education" (Human Resource and Skill Development Canada). In a 2007 Canadian survey of high school students, $43 \%$ of disabled students were planning to go onto post-secondary education compared to $71 \%$ who did not identify as having a disability (Malatest \& Associates, 2007 in Kirby, 2009). Williams (2006) reports that about one third of persons with disabilities employed have a post-secondary certificate or diploma. However, this is still much lower than the general population wherein approximately $48 \%$ of the population have a post-secondary certificate or diploma. 
Although Canada certainly needs to improve its record as far as people with disabilities are concerned, there have been some significant policy developments during the past two decades: For example, Canadian Human Rights Act (1977) and the Canadian Charter of Rights and Freedoms (1982) include protection of people with disabilities; all provincial and territorial human rights legislation provides coverage to people with disabilities, and in April 2010 Canada ratified the United Nations Charter for the Protection of the Rights of People with Disabilities (2010).

While there have been improvements to the lives of Canadians with disabilities in recent years, the struggle for improved quality of life continues. Greater access to a post-secondary education for people with disabilities would address many quality of life issues. As the authors share their experiences of working toward greater accessibility and accommodation within postsecondary education, they will begin with the historical and ideological development of the Persons with Disabilities Caucus of the Canadian Association of Schools of Social Work (now named the Canadian Association of Social Work Education), moving to focus on organization change and policy development, and concluding with a research report on the status of disability inclusion within Canadian Schools of Social Work.

\section{Literature Review}

From a social justice perspective, the authors believe that disability discourse and the accommodation of people with disabilities within post-secondary institutions must be linked to debates pertaining to oppression and discrimination (Dunn, Hanes, Hardie, Leslie, \& MacDonald, 2008; Dunn, Hanes, Hardie, \& MacDonald, 2006). Canadian history is riddled with examples of marginalization; for example, the last racially segregated school in the province of Nova Scotia, 
Canada remained in operation until 1983 (Dominion Institute, n.d.). Some universities had quotas on the number of Jews to be admitted, as illustrated by the Jewish quota at the University of Toronto, Medical School in the late 1950's (Levi, 2003). Women were excluded from designated 'male faculties', for example, it wasn't until 1943 that "men only admitted" was removed from Queens University Medical School calendar (Cataudella, 1999). Such practices are no longer acceptable in liberal democratic countries such as Canada. However, while not overtly stated similar practices that directly or indirectly restrict opportunities for people with disabilities do exist. Post-secondary institutions need to embrace a disability-rights perspective by fostering inclusive environments that welcome disabled students. Able-ism, the discrimination of persons with disabilities by stereotyping and generalizations (Barker, 2003) should no more be accepted then racism, anti-Semitism, or sexism.

\section{Genesis of the Persons with Disabilities Caucus}

The Persons with Disabilities Caucus of the Canadian Association of Social Work Education has had many struggles over its eighteen years of existence. With the ultimate goal of promoting disability inclusion, accommodations, and curriculum, members have engaged in numerous battles and strategic maneuvers, resulting in many successes and occasional setbacks. Demographics within post-secondary education are changing. "Diversity has become a fact of life in higher education.”(Burgstahler, 2008, p. 4). Within the United States, Burgstahler (2008) notes that what used to be a campus of white, young, abled-bodied males is now represented by students from other racial/ethnic groups (25\%), women (over $50 \%$ ), older students, and students with disabilities (6\% or more). One Canadian school of social work just accepted one-third of the incoming class from designated equity categories, with $12.5 \%$ of campus BSW acceptances 
identifying as having a disability (Dalhousie University, 2010). Post-secondary institutions, faculties, departments, and professional schools have a responsibility to address the educational needs of all students, including students with disabilities. A fundamental purpose of the Persons with Disabilities Caucus is to ensure that all schools of social work in Canada accept this responsibility; ultimately meeting the educational needs of all disabled social work students.

The Persons with Disabilities Caucus of the Canadian Association of Social Work Education (CASWE) was founded in June 1993. The development of the caucus emanated from a two-day conference hosted by Carleton University, School of Social Work, Ottawa, Canada, in conjunction with the CASWE Annual General Meeting and the Congress of the Humanities and Social Sciences. The establishment of the conference and the resulting Persons with Disabilities Caucus did not happen in isolation from other events. The conference was precipitated by two important events; one, a course on Social Work and Persons with Disabilities (Hanes, 1993), one of the first in Canada; and, two, a faculty/student committee on disability issues formed the previous year at Carleton University. A grant of \$26,000 was received from the Disabled Persons Participation Programs, Department of Health and Welfare, Canada. The grant was used to cover operational, transportation and accommodation costs for twenty-seven people from across Canada including social workers working with people with disabilities, representatives of disabilities rights organizations, social workers with disabilities, disabled and nondisabled faculty members from schools of social work, and social work students with disabilities. The objectives of the conference were to address the lack of social work education and research pertaining to people with disabilities in Canadian schools of social work. The conference served to bring stakeholders together, including social work educators, practitioners, students, and persons with disabilities and to establish a working group to organize the Persons with Disabilities Caucus within CASWE 
(Wills and the Persons with Disabilities Caucus, 1993; Hanes, 1994). Issues discussed within the conference included, lack of resources in courses, course material and social work research, insufficient academic supports for, and isolation of, disabled students, and, the inaccessibility of schools of social work including field placements (Wills and the Persons with Disabilities Caucus; Hanes, 1993).

Prince (2009) identifies disability politics in Canada as having three components, "material (education, health care, income security), cultural (attitudes, beliefs, identities), and structural (autonomy, participation, collective voice)" (p. 192). The caucus has embraced these principles in the following way: material - through efforts to promote disability inclusion within postsecondary education; cultural - by challenging stereotypes, assumptions and biases pertaining to access and accommodation; and, structural - through continual efforts to include students, faculty and staff with disabilities as members of the caucus, at the same time promoting their participation in school governance.

The conference and the development of the Persons with Disabilities Caucus provided then and now, a context wherein people with similar interests are able to discuss common concerns, research, and educational interests. The gathering in 1993 brought greater visibility to persons with disabilities and created an opportunity to put disability issues, as well as the needs of people with disabilities, on the agenda of the Canadian Association for Social Work Education (Hanes, 1994). But most importantly, the gathering demonstrated the importance of collective action within academia by challenging the existing status quo of the CASWE specifically and schools of social work in general. 
The newly formed group of academics and students that joined together during the conference sought formal approval for the creation of the Persons with Disabilities Caucus within CASWE at the 1993 Annual General Meeting. A motion was brought forward to the membership to approve the formation of the caucus and to get a commitment from the organization to pursue educational equity for persons with disabilities, which would include the writing of educational policy statements and the development of accreditations standards for university social work education in Canada. The motion was carried unanimously and the Persons with Disabilities Caucus became formally established within the CASWE. Further, it was understood that CASWE would establish accreditation standards that would ensure the development of disability related courses and research, and the admission of persons with disabilities into social work programs. The 1993 conference and the creation of the Persons with Disabilities Caucus of the CASWE proved to be a pivotal moment in the history of social work education in Canada, offering guided principles to the caucus, the CASWE and schools of social work to this day.

\section{Creating Disability Inclusion}

Caucus initiatives moved slowly during the first few years of its existence, as the caucus members advocated for the development of an educational policy statement on disability inclusion and worked with other CASWE caucuses, including the Women's Caucus and the Students' Caucus, to push for organizational change, as outlined in Table 1 A Chronology of the Activities of the Persons with Disabilities Caucus. Over the years caucus members presented papers at the annual CASWE conference, challenged organizational policies, such as the Professional Unsuitability policy brought forward in 2003, and consistently worked toward raising awareness of disability 
accommodations and inclusion within the membership. In 2003, caucus members crafted a survey to be sent to schools of social work within Canada, asking about their practices for admission and accommodation for students with disabilities and curriculum pertaining to disability rights and advocacy. A 10-page comprehensive questionnaire was sent to the 35 Directors of schools of social work across the country, yielding a $71 \%$ return rate.

The 2003 survey of Canadian schools of social work, the first study of its kind in Canada to investigate how schools of social work were addressing the needs of people with disabilities, produced two significant findings. First, while schools identified university wide policies on students with disabilities, only one-third of the schools had school specific disability policies and of these only $17 \%$ had written policies. Second, the survey findings indicated that the number of students who identified as having a disability declined as the data collection moved from Bachelor (5.5\%) to Masters (4.1\%) to PhD social work programs (1.3\%). Not surprisingly, this translated to a similar pattern with the number of faculty (4\%) and staff (3\%) who identified as having a disability. While $72 \%$ of the schools had employment and education equity policies, few schools actively recruited faculty, staff, or students with disabilities. Less than a quarter of the schools had accommodation policies for students with disabilities in field practicum. Dunn et al. (2006) recognizes that "for accommodations to be realized, budgetary allocation, attitudinal acceptance, and governance/policy structure need to be part of the infrastructure (p. 13).

In 2005, the Persons with Disabilities Caucus hosted a national conference 'Promoting Disability Inclusion in Canadian Schools of Social Work' at the University of Manitoba (Winnipeg). The conference presentations and its related discussions included such topics as accommodations for students, faculty, and staff, curriculum development in disability rights and inclusion, and promoting social change. The presentations were recorded and used to develop a 
video and workbook that was distributed to all schools of social work in Canada. The teaching kit was an educational tool to help schools address issues of accommodation, inclusion and disability curriculum that could be adapted to other professions and other academic disciplines (Canadian Association of Schools of Social Work, 2007). To this point the authors have focused on the historical underpinnings of the Persons with Disabilities Caucus, including policy development and previous research. In the remainder of this paper, the authors will focus on the most recent research conducted by caucus members regarding social work and disability in Canadian schools of social work (2010-2011).

\section{Method}

The Canadian Association for Social Work Education, Standards for Accreditation stipulate that, at the Bachelor of Social Work and Masters of Social Work levels (SB 5.10.17 and SM 5.7.12.):

The curriculum shall ensure that the student will have: An understanding of theories relevant to disability and their implications for social policies and the practice of social work (CASWE, 2008).

The authors approached Canadian schools of social work regarding disability inclusion by requesting information about courses, programs, field experiences, scholarly activities, accommodation practices, equity policies re: admission, and the number of students with disabilities within their programs. The primary objective of the research was to gather information 
about the nature of disability education in Canadian schools of social work. By soliciting information from the Deans and Directions of Canadian schools of social work, the researchers hoped to be able to reflect on how social work educators have included disability content in social work education and how they have made education more accommodating and inclusive for people with disabilities.

\section{Data Collection}

There are thirty-six Canadian schools of social work accredited by the Canadian Association of Social Work Education. In 2010, a letter was sent to the Deans and Directors of twenty-seven accredited English-speaking schools of social work. If the researchers did not receive a response within a two-week period subsequent emails and telephone calls were made to the Deans and Directors or other designated faculty, such as MSW and BSW Program Coordinators or to Persons with Disabilities Caucus members. If after two requests a response was not forthcoming, a third follow up attempt by email or telephone was made. In 2010, a total of twenty out of twenty-seven English-speaking schools responded to the questionnaire. In 2011, after securing translation services, the questionnaire was issued to nine French-speaking schools of social work and reissued to the seven English-speaking schools that had not responded the year previous. Of the seven English-speaking schools of social work, three responded to the survey for a total of twentythree out of a possible twenty-seven responses. In addition, four of the nine French-speaking schools responded to the questionnaire. In short, there was a $75 \%$ response rate with a total of twenty-seven out of a possible thirty-six schools of social work being represented. 
The Deans and Directors were asked to relate what efforts their particular schools were making in creating an inclusive environment and generating scholarly work related to disability, as outlined in Table 2 Survey on Disability Inclusion within Canadian Schools of Social Work, 2010 - 2011. The content of the responses from these schools is summarized in the following section.

\section{Findings}

The most impressive finding emanating from the 2010 - 2011 survey is the significant shift in momentum toward disability services and curriculum development. While variations between schools still exist, the data suggests that courses and programs on disability, as well as service provisions, have been moving at an accelerated pace.

\section{Programs and Courses}

Twenty-three of the twenty-seven Deans or Directors who responded to the survey indicated that at least one course related to persons with disabilities was offered in their school of social work. Further, results show that most Canadian social work programs have specific courses on disability, with a range of 1 to 3 disability related courses being offered. Findings further suggest that all programs integrated topics on disability into a variety of BSW and MSW courses, especially courses pertaining to direct practice, social policy, and diversity. Some schools also mentioned that course work relevant to disability focused on the intersectionality of marginalized populations. One school of social work combined courses from a university based disability studies program and social work as a means for creating opportunities of greater integration. 


\section{Committees}

Less than $50 \%$ of the Deans and Directors of schools of social work who responded to the questionnaire reported committee activity by faculty and students related to disability. Four of the schools described committees that were student driven and concentrated on accessibility. Other committee activities reported involved broader university committees on disability issues and board membership in community disability focused agencies.

\section{Field Experiences}

Findings from the questionnaire suggest that most social work programs had several disabilityrelated field placements and a large portion of these placements included direct service provision to persons with disabilities. Four programs did not offer placements that specifically dealt with disability issues. Interestingly, given the strong probability that social workers will work with disabled persons, be it in areas of mental health, health care or working with elders, the connection to disability theory and practice often was not explicit, as the relationship of disability to field was not highlighted in most programs. Another pressing issue that needs further exploration is the accommodation needs of students with disabilities within their field placements. Each school of social work should have formalized policies pertaining to students with disabilities accommodations within field placements. Questions such as, 'Are agencies equipped to accommodate students with disabilities?'; 'what is the relationship between the university accommodation services and field agencies?' and 'what barriers have students with disabilities encountered within their field placement experiences?' need to be explored. 


\section{Scholarly Activities}

Seven of the respondents reported that faculty and graduate students were conducting research on disability. In addition, several universities were doing presentations and/or organizing conferences on disability, as well as assisting graduate students, at both the MSW and $\mathrm{PhD}$ level, with research on disability. An increase in disability scholarship most likely is contributed to the establishment of accreditation standards pertaining to ableism and disability rights curriculum established in 2009. This raises concerns for the new accreditation standards (CASWE, 2011a) do not specifically identify ableism or disability curriculum. The standard is now streamlined under the category of diversity.

\section{Equity}

Most schools provided an opportunity for applicants to the BSW and/or the MSW programs to declare disability as part of an education equity statement in the admission process and a few Deans and Directors mentioned that their schools also included equity statements in the hiring process for faculty and staff. In previous research by caucus members, Dunn et al. (2008) advocated greater equity in Canadian schools of social work by encouraging recruitment and admissions standards that promote disability inclusion. These authors reference social work's history of advocacy for persons with disabilities and propose equity admissions policies as an essential responsibility of social work educators. Crosby and Clayton (2004) advocate affirmative action as the only effective method for addressing discrimination. 


\section{Number of Students}

Most Deans and Directors indicated that students might not disclose their disability due to the continued stigma attached to disability. Equity and anti-discrimination legislation protects applicants from the requirement to declare medical problems and obligates universities to make reasonable adjustments to accommodate the students when these problems are presented as disabling. Thus, most Deans and Directors were unsure of the actual number of students with disabilities enrolled in their social work programs. Having stated this, most Deans and Directors reported that their universities had a disability student services office wherein students could discuss accessibility issues privately and apply for educational supports and services. .

\section{Limitations}

Although the response rate was high for the English-speaking schools (twenty-three out of a possible 27), the response rate from the French-speaking schools was less than fifty per cent (four out of a possible nine). Also, the data was primarily received from Deans and Directors who might have an invested interest in having their schools' appear more accommodating and accessible than that was actually the case. Surveying faculty, students, and staff could provide a

fuller picture of the experiences of disabled students. Further, due to time limitations and a lack of funding the method of inquiry was not as systematic or as structured as it could have been, for example recruitment span over two years because funding for translation services was not available. Finally, one group member secured the assistance of a bilingual colleague. The authors realize that future directions should include collecting course syllabi for disability related courses and for each course that may have a designated disability component to it as this will provide a 
more detailed picture of what is being taught about disability in schools of social work. Ideally, it would be helpful to conduct a full document analysis of each school, as well as interview faculty, students and administrators to develop a more complete understanding of how each school actually embraces disability inclusion.

\section{Discussion}

Since its inception, members of the Persons with Disabilities Caucus have asserted that postsecondary education is a right and a social work education should not be denied to persons with disabilities. The Persons with Disabilities Caucus adheres to the belief that schools of social work should have education equity policies, which include people with disabilities. In addition to equity based admission policies, universities and schools of social work need to develop accessibility standards that would include accommodations for assignments, exams, and presentations, along with technical and personal supports. Accessibility to social work education needs to be more than a barrier free environment (CASSW, 2007). Inclusionary measures should not be developed in such a manner as to "compromise existing standards of academic and practice competence" (Wills et al., 1993). Equity does not equal sameness. Certain groups within society have been educationally marginalized and to address this inequity, specific measures are necessary (MacDonald, Bernard, Campbell, Fay, MacDonald, \& Richard, 2003). These measures involve accessible work environments, curriculum development, and awareness and advocacy as outlined in the following discussion. 


\section{Accessible Work Environments}

Students presented the lack of instructors with disabilities as an issue at the inaugural meeting of the caucus in 1993. Equity admissions of students and equity hiring of faculty members with disabilities are an important component of disability inclusion within post-secondary education. As identified earlier in this paper, initial research by the Persons with Disabilities Caucus found that faculty and staff with disabilities represented less than five percent of employees (Dunn et al., 2006). The lack of people with disabilities within PhD programs in Social Work, 1.3\% (Dunn et al.), suggests that these numbers are not going to improve in the near future. Disability inclusion needs to be at all levels within the academy.

\section{Curriculum Development}

A core objective of the Persons with Disabilities Caucus has been the development of more social work courses pertaining to people with disabilities. In 1993, there were only two core courses offered on a regular basis at schools of social work in Canada. Now, out of the twenty-seven schools surveyed, twenty-three schools had at least one course related to disability. In recent years, caucus members have written about the need to develop courses specializing in disability, as well as the need to offer generalist courses that have content directed at social work and people with disabilities (Dunn et al., 2008; Carter, Leslie and Angell, 2011). All social work students should have basic disability content and the option to delve deeper into disability scholarship should also be available to students. Opportunities to explore disability scholarship can be provided through independent studies, thesis research, interdisciplinary studies, and programs in disability studies (Carter, Quaglia, \& Leslie, 2010). 


\section{Awareness and Advocacy}

Academics within social work and the universities in general are not always aware of the needs of students with disabilities, nor do they possess knowledge of pertinent disability theories or disability related research. Over the years members of the Persons with Disabilities Caucus have attempted to address this underdevelopment by engaging in activities and research aimed at increasing faculty awareness through research, course teachings, guest lecturing, and advocacy. As a small collective, representing schools of social work from across Canada, members of the caucus have contributed to changes that have made social work education more inclusive for people with disabilities. Members of the caucus encourage faculty members to broaden their course material by including ableism as part of the analysis and classroom discussions. Members of the caucus have been instrumental in getting equity statements expanded to include people with disabilities thus encouraged more people with disabilities to apply to BSW and MSW programs. Moreover, caucus members have challenged their own universities to be more accessible and more supportive of students with disabilities (Carter, Leslie \& Moore, 2010; MacDonald \& Farry, 2009). And, members have advocated within their own professional body to have disability curriculum and accommodations included within the accreditation standards for all schools of social work. Advocating for change has been part of the legacy of the caucus, it was a founding principle of this caucus, and members continue to work diligently toward disability rights and inclusion.

\section{Barriers Faced by the Persons with Disabilities Caucus}


One of the most significant barriers to the advocacy work and research of the Persons with Disabilities Caucus was the lack of funding. Member worked with a 'shoe-string' budget, only receiving between five hundred and one thousand dollars annually from the CASWE, and supplementing this funding with in-kind support from the members' host universities. CASWE occasionally provided office support in the form of translation and mail services. Caucus members sought funding from federal government departments but with the exception of the inaugural conference in 1993 funding was never secured. Without creative maneuvers and the ability to draw upon individual schools for services like research assistants, teleconferences, photocopying and office supplies, the work of the caucus would never have come to fruition.

Another barrier that remains constant along the lifespan of the Persons with Disabilities Caucus is the struggle for increased membership. The active working group of the caucus has been between three and six members. Members have been faculty and students from schools across the country, who traditionally only get together once a year at the association's annual conference. Extra efforts have to be made to stay connected through such means as teleconferences, e-mails and website communication. Caucus work is volunteer time; it is not regarded as part of deployment for faculty workload, it is often not well recognized for tenure and promotion nor is it awarded credit value for students. Members juggle the demands of their jobs, research, writing and publications in other areas, family responsibilities and for many, health issues associated with living with a disability. Student members have the additional demands of their programs. Members have to be truly dedicated to disability rights of inclusion in order to stay focused and continue this invaluable work.

In addition to the lack of funding and low membership numbers, the most significant barrier to disability inclusion, access and accommodation has been the lack of awareness disability 
issues have received within the academy, and specifically, within schools of social work and

CASWE. Ableism needs to be acknowledged as part of the anti-oppressive discourse within schools of social work and universities. It took 16 years, from the beginnings of the caucus to the establishment of Accreditation Standards to reach the point where all social work schools in Canada were mandated to provide accommodations to students with disabilities and include disability curriculum as a required field of study. Interestingly, in an attempt to address racism with social work education, the association fully funded and sponsored a national examination of schools of social work between 1998 and 1999 (CASSW, n.d.). Research was conducted, consciousness-raising tools were developed, and site visits were available to help schools develop policies, procedures, and curriculum pertaining to anti-racism. Members of the Persons with Disabilities Caucus supported these efforts and have advocated for similar funding for the work of the caucus. However, as stated earlier, this was not forthcoming, as funding remained a struggle through all of the endeavors of the caucus. The Persons with Disabilities Caucus had to work relentlessly to keep disability-rights on the platform of CASWE and its associated schools. Part of the caucus' mission was to "destabilize dominant ways of knowing disability" (Snyder and Mitchell, 2006 in Titchkosky, 2007, p. 5) to unsettle how disability is understood in our culture as "a clear-cut problem in need of a solution, . . . as an undesired difference, . . as an add-on" (Titchkosky, 2007, p. 9). Rethinking disability, be it in the form of pedagogy, curriculum, services to students, faculty or staff with disabilities, needs to be part of each and every school of social work in Canada and abroad.

\section{Collaborative Alliances as Pathways to Success}


As noted above, getting disability recognized as an important issue within schools of social work, the Canadian Association of Social Work Education and the academy has been a long struggle. Through sharing the lessons learned in this journey it is hoped that others will be able to deem insights to help facilitate making their learning environments more accessible and accommodating to students, faculty, and staff with disabilities within post-secondary educational institutions.

One of the most significant lessons learned from the work of the Persons with Disabilities Caucus has been the necessity of a multi-layered approach to change. The journey toward inclusive social work education has involved organizational examination and change, policy analysis and development, and curricular review and implementation. Organizational change began with the establishment of the Persons with Disabilities Caucus in 1993 and continues as a focus today. As an example, in May 2011 at the Annual General Meeting of CASWE the various caucuses of the Association were not identified on an organizational chart being presented to the overall membership (CASWE, 2011b). Members of the Persons with Disabilities Caucus lobbied CASWE executive board members prior to the meeting and raised their concerns at the AGM. As a result of this action, a motion was passed to amend the chart and subsequently the various caucuses were included (CASWE, 2011c).

From its very inception the Persons with Disabilities Caucus recognized that there were no policies on accommodations for students with disabilities within CASWE's Accreditation Standards, which is the document that governs the performance of schools of social work across the country. The original motion to create the caucus identified this initial concern, yet it took years of lobbying, networking and consciousness-raising to finally have accreditation standards implemented to acknowledge and support students with disabilities (CASWE, 2008). Unfortunately, in May 2011, a taskforce charged with streamlining the Accreditation Standards for 
the CASWE presented changes to the membership that had significantly diminished the gains related to disabilities that had been accomplished just two years prior, including curricular emphasis on ableism (CASWE, 2011, c). The caucus raised these concerns with the board and the membership alike and prepared a report to the taskforce. The work of the caucus continues as focus is now on ensuring that the gains realized in 2008 are not lost.

The gains the Persons with Disabilities Caucus has achieved over the years could not be realized if it were not for networking, building alliances and collaborating within and outside the organization. From the very beginning, the Persons with Disabilities Caucus was formed because people came together out of concern for students with disabilities' access to post-secondary social work education. While the caucus membership has been small, members stretch across Canada, coming from Dalhousie University in Atlantic Canada, Carleton University, Ottawa, Wilfrid Laurier University and the University of Windsor in Central Canada, and the University of British Columbia (Fraser Valley) and University of Manitoba in the West. As a working group, members of the caucus adhere to the same principles of inclusion and access, whether members live with a disability, have family members with disabilities, or have worked in the field, demonstrating aligned commitments to disability rights.

The Persons with Disabilities Caucus has been strategic in forming alliances with other caucuses within CASWE to promote organizational change. On its own the Persons with Disabilities Caucus could not prevent problematic policies or organizational change from ensuing, however, with the support of the Student Caucus, the Women's Caucus, and the Lesbian, Gay, Bisexual and Transgender Caucus, resistance can be stirred and much can be accomplished. For example, in the last few years the Standing Committee on Racial and Ethnic Affairs of the CASWE pulled panels of diverse faculty together to present on emerging issues within anti- 
oppressive theory and practice. A member from the Persons with Disabilities Caucus has been involved in each of the presentations involving topics such as teaching from the margins and diversity within the academy. Such initiatives help consciousness-raise about pressing issues and demonstrate the intersectionality of oppression, be it originating from race, sex, class, ability, and excreta.

Within the larger university structure, the Persons with Disabilities Caucus members have been involved in interdisciplinary work. This work included being founding members of the Canadian Disability Studies Association (2004), which united academics from a number of disciplines, including history, sociology, anthropology, political science, and women studies, to mention just a few. Other examples include the creation of disability studies programs such as the one established at the University of Windsor and the one in its development stage at Carleton University. Working with disability rights activists from the community, other academic disciplines and within social work helps inform the issues and provides a broader understanding of the complexities involved.

Members of the Persons with Disabilities Caucus adhere to the ideal of social justice, believing that all members of society should have equal opportunities and that historical inequalities caused by discrimination and institutional inequities should be addressed. Exercising principles of social justice, leading by example and instituting change through advocacy has led caucus members through many hurtles and toward their goals of disability inclusion. Beyond caucus work and promoting disability inclusion within CASWE, caucus members have been actively involved in promoting disability access and accommodation within their own universities and communities. Members push universal design principles within their universities, be it structural (as in access to buildings) or instructional (pedagogical principles of inclusion). They 
work with disability organizations, such as Independent Living Centres or the Council of Canadians with Disabilities, and they promote and engage with disability research. Being involved in various and multiple areas of interaction with disability inclusion provides a holistic perspective in which to inform change.

Finally, perhaps the most significant learning from the experience of the Persons with Disabilities Caucus membership has been the realization that change is possible and to never underestimate the power of a small group of people who are committed toward a common goal. From the beginning, the Persons with Disabilities Caucus established a vision, worked toward their goals, one step at a time, not letting set-backs derail their mission or get in the way of the vision of an accessible, inclusive and accommodating education for all students, faculty and staff with disabilities within post-secondary social work education. As Jack Layton repeatedly proclaimed “don't let them tell you it can't be done" (Layton, 2011). 


\section{References}

Barker, R. L. (2003). The social work dictionary ( $5^{\text {th }}$ ed.). Washington, DC: NASW Press.

Burgstahler, S. (2008).Universal design in higher education. In S. Burgstahler and R. Cory (Eds.), Universal design in higher education: From principles to practice, pp. 3 - 20. Cambridge, MA: Harvard Education Press.

Canadian Association of Social Work Education (CASWE). (2011a). Accreditation standards revised April 2011. Retrieved from http://www.caswe-acfts.ca/en/What's_new_46/items/4.html

Canadian Association of Social Work Education (CASWE). (2011b). Governance task force: Organizational chart. Retrieved from http://www.casweacfts.ca/en/What`s_new_46/items/7.html

Canadian Association of Social Work Education (CASWE). (2011c). Minutes from annual general meeting, May $31^{\text {st }}$. Retrieved from http://www.casweacfts.ca/en/AGM_35.html

Canadian Association of Social Work Education (CASWE). (2009). Educational policy statements. Retrieved from www.caswe-acfts.ca/en/20/items/1.html

Canadian Association of Social Work Education (CASWE). (2008). Standards of accreditation. Retrieved from www.caswe-acfts.ca/en/20/items/1.html

Canadian Association of Schools of Social Work (CASSW). (2007). Persons with disability caucus. Promoting disability Inclusion in Canadian schools of social work [DVD]. Available from http://www.caswe-acfts.ca/en/

Canadian Association of Schools of Social Work (CASSW). (n.d.). Anti-racist training 
and materials project. Retrieved from http://www.mun.ca/cassw-ar/links/

Canadian Charter of Rights \& Freedoms. (1982). Retrieved from http://laws-

lois.justice.gc.ca/eng/charter/

Canadian Disabilities Studies Association (CDSA). (2004). Retrieved from

http://www.cdsa-acei.ca/

Canadian Human Rights Act. (1977). Retrieved from

http://laws-lois.justice.gc.ca/eng/acts/h-6/index.html

Carter, I. Leslie, D., \& Moore, S. (2010). Developing effective guidelines for faculty teaching first-year university students. Collective Essays on Learning and Teaching, III, 146-152.

Carter, I., Quaglia, C., \& Leslie, D.(2010). Enriching social work through interdisciplinary disability studies. Collected Essays on Learning and Teaching, III, 124-130.

Carter, I., Leslie, D., \& Angell, B. (2011).Promoting accessibility and adding value to social work education. Professional Development: The International Journal of Continuing Social Work Education, 14(1).

Cataudella, J. (1999). When women came to Queens. CMAJ, 16(5), 575-576.

Crosby, F, \& Clayton, S. (2004). Affirmative action and the search for educational equity. Analyses of Social Issues and Public Policy, 4(1), 243-249.

Dalhousie University. (2010). School of social work admission statistics. Halifax, Nova Scotia.

Dominion Institute. Black history Canada. Retrieved from http://blackhistorycanada.ca/events.php?themeid=21\&id=9 
Dunn, P., Hanes, R., Hardie, S., Leslie, D., \& MacDonald, J. (2008). Best practices in promoting disability inclusion within Canadian schools of social work. Disability Studies Quarterly, 28(1) 13-20.

Dunn, P. Hanes, R., Hardie, S. \& MacDonald, J. (2006). Creating disability inclusion within Canadian schools of social work. Journal of Social Work in Disability and Rehabilitation, 5(1), 1-19.

Dunn, P., Hanes, R., Hardie, S., Leslie, D., and MacDonald, J. (2006). Promoting inclusion for people with disabilities in social work education. Presentation at the Canadian Disability Studies Association annual conference, Congress of the Humanities and Social Sciences, York University, Toronto, Ontario.

Dunn, P., Hanes, R., Hardie, S., Leslie, D., \& MacDonald, J. (2005). The transformation of persons with disabilities from clients to colleagues: An overview of best practices in social work. Presentation at Canadian Association of Schools of Social Work, Congress of the Humanities and Social Sciences, Western University of Ontario, London, Ontario.

Dunn, P., Hanes, R., Hardie, S., Leslie, D., and MacDonald, J. (2004). Ways to promote disability inclusion in Canadian Schools of social work. One-day forum pre Congress of the Humanities and Social Sciences, University of Manitoba, Winnipeg, Manitoba.

Dunn, P. Hanes, R., Hardie, S. and MacDonald, J. (2003). Disability: From curriculum to accommodations: A decade of reflections. Presentation at the CASSW annual general meeting, Congress of the Humanities and Social Sciences, Dalhousie University, Halifax, Nova Scotia. 
Hanes R. (1993). Course development - Social work and persons with disabilities.

Retrieved from http://www1.carleton.ca/socialwork/people/hanes-roy

Hanes, R. (1994). Activity report for the establishment of a persons with disabilities

caucus in Canadian schools of social work: Report for the federal government of Canada, Disabled Persons Participation Programs.

Human Resource and Skill Development Canada. (2007). 2006 - 2007 Department

tracking survey - consolidated report. Retrieved from

http://www.hrsdc.gc.ca/eng/publications_resources/por/subjects/general_sentimen

ts/2007/21606/page00.shtml

Kirby, D. (2009). Widening access: Making the transition from mass to universal post-secondary education in Canada. Journal of Applied Research on Learning, 2(Special Issue, Article 3), 1-17.

Layton, J. (2011). Jack Layton's last letter to Canadians. Retrieved from http://www.cbc.ca/news/politics/story/2011/08/22/pol-layton-last-letter.html

Levi, C..(2003). "There is a definite limitation imposed". Historical Studies in Education. Spring Edition. Retrieved from http://ibrary.queensu.ca/ojs/index.php/edu_hse-rhe/article/viewArticle/477/657

Lewis-Fleming, G. (2007). The military child with special needs transitioning to adulthood. The Exceptional Parent, 37(8), 68-76.

Malatest \& Associates. (2007). The class of 2003: High school follow-up survey. Montreal, QC:

Canada Millennium Scholarship Foundation in D. Kirby (2009) Widening access:

Making the transition from mass to universal post-secondary education in Canada.

Journal of Applied Research on Learning Vol. 2, Special Issue, Article 3. 
MacDonald, J. \& Farry, P. (2008, Fall). Distance social work education: Building accessibility, community, and diversity on-line. Ontario Association of Social Workers Newsletter. Toronto, Ontario.

MacDonald, N., Bernard, W., Campbell, C., Fay, J., MacDonald, J. \& Richard, B. (2003). Managing institutional practices to promote and strengthen diversity: One school's journey. In Wes Shera (Ed.), Emerging perspectives on antioppressive practice (pp. 467 - 487). Toronto, ON: Canadian Scholar's Press.

Milsom, A., \& Hartley, M. (2005). Assisting student with learning disabilities transitioning to college: What school counselors should know. Professional School Counselling, 8(5), $436-441$.

Prince, M. (2009). Absent citizens: Disability politics and policy in Canada. Toronto, ON: University of Toronto Press.

Snyder, S. \& Mitchell, D. (2006). Cultural locations of disability. Chicago, ILL: University of Chicago Press.

Titchkosky, T. (2007). Reading \& writing disability differently: The textured life of embodiment. Toronto, Ontario: University of Toronto Press.

United Nations. (2006). Convention on the rights of persons with disabilities. Retrieved from http://www.un.org/disabilities/convention/conventionfull.shtml

Williams, C. (2006). Disability in the workplace; Perspectives on labour and income. Retrieved fromhttp://www.statcan.gc.ca/pub/75-001-x/10206/9096-eng.htm 
Wills, G., \& Members of the Persons With Disabilities Caucus (1993). Workshop on persons with disabilities and social work education in Canada. Ottawa: Canadian Association Schools of Social Work. 
Table 1

A Chronology of the Activities of the Persons with Disabilities Caucus

Date Activity/Event

1993

Establishment of the Persons with Disabilities Caucus.

1995 Women's caucus, student caucus and disability caucus held a joint meeting to develop strategies regarding the Board of Directors platform at the Annual General Meeting (AGM). Caucus funding was being threatened.

$2001 \mathrm{PhD}$ students with disabilities invest in Caucus work.

2002 Continued discussions on adapting an Educational Policy on disability.

2003 Presentation CASSW Congress, Dalhousie University - Disability: From Curriculum to Accommodations: A Decade of Reflections. Caucus members discussed and planned survey of schools of social work across the country re disability policies and curriculum; surfaced idea of Disability Conference as a pre-congress workshop for the following year.

2003 CASSW AGM - Educational Policy Committee presented a policy on 'Professional Unsuitability’ for vote. Disability Caucus members voiced concern for discriminating against students with disabilities through this policy, lobbied with Student Caucus to work 
together to block the motion.

2003 CASSW AGM - Educational Policy Committee presented a policy on 'Professional Unsuitability’ for vote. Disability Caucus members voiced concern for discriminating against students with disabilities through this policy, lobbied with Student Caucus to work together to block the motion.

2003 Caucus members were asked to advise the Educational Policy Committee re finding a way forward that would respect students with disabilities while upholding professional conduct. No compromise was found.

2004 University of Winnipeg - Disability Forum - faculty, students, community workers - both disabled and able-bodied - filmed presentations. Later information from this forum was used to put together an educational tool on accessibility within schools of social work.

2005 Presentation at CASSW Congress, Western University of Ontario - "The Transformation of Persons with Disabilities from Clients to Colleagues: An Overview of Best Practices in Social Work."

2005 Began discussing an Educational Policy statement and subsequent Accreditation Standards re disability.

2006 Article published on research findings - 'Creating Disability Inclusion within Canadian Schools of Social Work' in the Journal of Social Work in Disability and Rehabilitation.

2006 Presentation at Canadian Disability Studies Association, Congress, York University "Promoting Inclusion for People with Disabilities in Social Work Education". 
2006 Through lobbying efforts a Caucus member was invited to serve on the Educational Policy Committee.

2007 Promoting Disability Inclusion in Canadian Schools of social work - educational package including a video and accommodation information was sent out to every School of Social Work in Canada, including a workbook to guide the Schools' through their own policy review around disability inclusion.

2007 Motion re Educational Policy on disability was accepted at the AGM at the University of Saskatchewan. Educational policy 1.8 "Schools shall respond to the needs of faculty, students, and staff with disabilities through the education process including recruitment, hiring, admissions, accommodations, curriculum, field practicum, retention, and graduation."

2008 CASWE (formerly CASSW) held their AGM and conference in collaboration with the Canadian Association of Social Workers (the professional association) - Toronto. Witnessed a major challenge to Accreditation Standards in response to the Educational Policy Statement on disability.

2008 Article published on best practices from the survey research - 'Best Practices in Promoting Disability Inclusion within Canadian Schools of social work' in Disability Studies Quarterly.

2009 CASWE Conference, Carleton University. Intersection of Oppression: Panel discussion, moderated by Ben Carniol and Jennifer Clarke. Disability Caucus member was an invited 
panellists.

2009 Caucus website established - for the sharing of course outlines, articles and other resources amongst caucus members.

2010 Caucus members present papers at the CASWE Conference, Montreal. 'Disability and family: linking critical disability theory and family involvement through the structural approach to social work'; and 'Best practices in providing specialized mental health services to individuals with a dual-diagnosis'.

2010 Research regarding Canadian schools of social work accomplishments in areas of accessibility, accommodation and course development. Findings to be presented at the $7^{\text {th }}$ International Conference on Higher Education and Disability - Innsbruck, Austria.

2010 Caucus presentation at the $7^{\text {th }}$ International Conference on Higher Education and Disability - Innsbruck, Austria. Follow-up to survey research; contacted Schools re disability accommodations and curriculum, as a result of circulated educational material and implemented Accreditation Standards.

2011 Caucus presentation at the AHEAD conference in Seattle, Washington. Eighteen years of advocacy promoting institutional change re disability inclusion, along with updated research findings on disability within Canadian Schools of Social Work including francophone schools 
Table 2

Survey on Disability Inclusion within Canadian Schools of Social Work 2010 - 2011

Questions:

- Does your school have any courses pertaining to social work and people with disabilities?

- If so, at what level... BSW or MSW or both?

- If such courses exist, how long have they been in existence?

- How many students are usually enrolled in the course on an annual basis?

- Are you aware of students, BSW or MSW, who are doing field placements with agencies that deal specifically with people with disabilities?

- Does your school collaborate with other departments that offer courses on disability or programs of study on disability?

- Does your school have any persons with disabilities caucus or persons with disabilities committees?

- Does your school integrate the study of disability in courses related to direct practice, social policy or diversity?

- Does your school have an equity statement that addresses the needs of students with disabilities?

- How many students with disabilities are enrolled in your BSW program at the present time?

How many students with disabilities are enrolled in your MSW Program at the present time? 